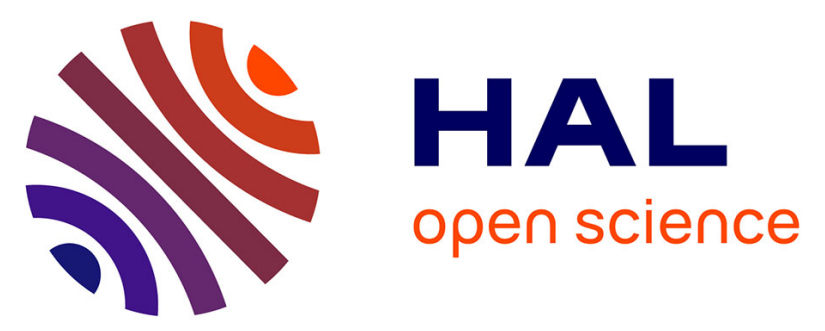

\title{
Comparative study of enzymatic activities of new KatG mutants from low- and high-level isoniazid-resistant clinical isolates of Mycobacterium tuberculosis
}

Florence Brossier, Marlène Boudinet, Vincent Jarlier, Stéphanie Petrella, Wladimir Sougakoff

\section{To cite this version:}

Florence Brossier, Marlène Boudinet, Vincent Jarlier, Stéphanie Petrella, Wladimir Sougakoff. Comparative study of enzymatic activities of new KatG mutants from low- and high-level isoniazidresistant clinical isolates of Mycobacterium tuberculosis. Tuberculosis, 2016, 100, pp.15-24. 10.1016/j.tube.2016.06.002 . hal-01339438

\section{HAL Id: hal-01339438 \\ https://hal.sorbonne-universite.fr/hal-01339438}

Submitted on 29 Jun 2016

HAL is a multi-disciplinary open access archive for the deposit and dissemination of scientific research documents, whether they are published or not. The documents may come from teaching and research institutions in France or abroad, or from public or private research centers.
L'archive ouverte pluridisciplinaire HAL, est destinée au dépôt et à la diffusion de documents scientifiques de niveau recherche, publiés ou non, émanant des établissements d'enseignement et de recherche français ou étrangers, des laboratoires publics ou privés. 
3 Comparative study of enzymatic activities of new KatG mutants from low- and high-level isoniazid-resistant clinical isolates of Mycobacterium tuberculosis

Florence BROSSIER $^{\mathrm{a}, \mathrm{b}, *}$, Marlène BOUDINET ${ }^{\mathrm{a}}$, Vincent JARLIER $^{\mathrm{a}, \mathrm{b}}$, Stéphanie PETRELLA ${ }^{\mathrm{c}}$,

${ }^{\mathrm{d}}$, Wladimir SOUGAKOFF ${ }^{\mathrm{a}, \mathrm{b}}$

a Sorbonne Universités, UPMC Univ Paris 06, CR7, INSERM, U1135, Centre d'Immunologie et des Maladies Infectieuses (CIMI), Team E13 (Bacteriology), Paris, France;

b AP-HP, Hôpital Pitié-Salpêtrière, Centre National de Référence des Mycobactéries et de la Résistance des Mycobactéries aux Antituberculeux (NRC MyrMA), Bactériologie-Hygiène, Paris, France.

${ }^{\mathrm{c}}$ Unité de Microbiologie Structurale, Institut Pasteur, CNRS URA 2185, 25 rue du Dr Roux, Paris, France,

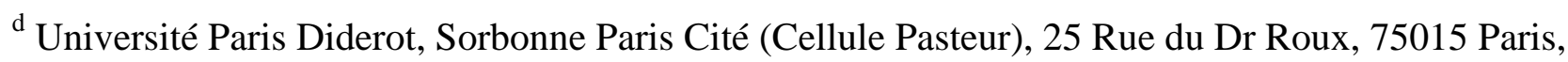

France

* Correspondence to: Florence Brossier, Laboratoire de Bactériologie-Hygiène, Faculté de

Médecine, Pitié-Salpêtrière, 91 boulevard de 1'Hôpital, F-75634 Paris Cedex 13, France. Phone: (+33) 1407797 46. Fax: (+33) 1458275 77. E-mail: florence.brossier@psl.aphp.fr

Abbreviations: G/Gox, glucose/glucose oxidase; IN•, isonicotinoyl acyl radical; INH, isoniazid; IN-NAD, isonicotinoyl-NAD; NBT, nitroblue tetrazolium; R, resistance; Rz, optical purity ratio of 


\section{ABSTRACT}

Resistance to isoniazid (INH-R) in Mycobacterium tuberculosis is mainly due to mutations at position 315 (S315T) of the catalase-peroxidase KatG. We identified 16 mutations (including 13 biochemically uncharacterized mutations) in KatG from INH-R clinical isolates of $M$. tuberculosis showing mutations other than S315T. The KatG enzymatic activities (catalase, peroxidase, free radical production and isonicotinoyl-NAD formation) of wild-type KatG and the 16 mutants were determined and correlated to their spatial location in a KatG model structure. Of all mutations studied, H270R, which conferred a high level of INH-R and results in the disruption of a coordination bond with the heme, caused complete loss of all enzymatic KatG activities. The mutants generally associated with a very high level of INH-R were all characterized by a drastic reduction in catalase activity and a marked decrease in INH activation activities. One mutant, A162E, displayed a behavior similar to S315T, i.e. a moderate decrease in catalase activity and a drastic decrease in the formation of the radical form of INH. Finally, the mutants associated with a low level of INH-R showed a moderate reduction in the four catalytic activities, likely stemming from an overall alteration of the folding and/or stability of the KatG protein.

(1)

1

2

3

4

5

6

7

8

9

6

1

2

3

4

5
66 
67 Key words: tuberculosis, resistance, isoniazid, catalase-peroxidase, KatG, enzymatic activities 68

69

70

71

72

73

74

75

76

77

78

79

80

81

82

83

84

85

86

87

88

89

90

91

92

93

94

95

96

97

98

99 


\section{INTRODUCTION}

Mycobacterium tuberculosis, the causative agent of tuberculosis, is the second leading cause of death worldwide among known infectious diseases. Isoniazid (INH), the cornerstone of front-line tuberculosis (TB) treatment, is a prodrug that needs activation by the kat $G$-encoded catalaseperoxidase [1, 2]. The activated form of INH targets the NADH-dependent enoyl-acyl carrier protein reductase InhA of the fatty acid biosynthesis type II system which is involved in the synthesis of mycolic acids [3, 4]. Resistance to INH (INH-R) has been previously reported to result mainly from mutations altering the activator protein KatG ( 70\% of INH-R isolates have a S315T mutation in KatG) [8-10], and secondarily to mutations in the InhA protein, which prevent the activated forms of the drug to bind to the target $[3,5]$, and in the inhA promoter that cause overexpression of the target InhA [6, 7].

KatG is a heme enzyme of the class I superfamily of fungal, plant, and bacterial heme peroxidases which exhibits both high catalase activity and a broad-spectrum peroxidase activity [11, 12]. In $M$. tuberculosis, the catalase-peroxidase is responsible for activating the prodrug INH [1]. Although the details of this chemical transformation are still under investigation, it is hypothesized that INH is converted into an isonicotinoyl radical which binds to $\mathrm{NADH} / \mathrm{NAD}^{+} / \mathrm{NAD}^{\circ}$, resulting in the formation of an isonicotinoyl-NAD (IN-NAD) adduct which acts as a potent inhibitor of InhA and interferes with cell wall biosynthesis [2, 13-16].

$\mathrm{KatG}$ is a functional homodimer in which each monomer is composed of two domains (Figure 1). The N-terminal domain contains a heme binding site in which the heme is surrounded by a proximal pocket (made up in part by His270 and Trp321 in Figures 1 and 2A) and a distal pocket (Trp107 and His108 in Figures 1 and 2A). A peculiar structural feature unique to KatG enzymes is the presence of two covalent bonds bridging the side chains of amino acids Trp107, Tyr229 and Met255 in the distal pocket, which is required for the catalase but not the peroxidase activity [1720]. The KatG heme is accessible to solvent through a narrow channel connecting the distal heme pocket to the outside of the protein. This pocket, which is bordered by amino acid Ser315 and filled by a network of organised water molecules (in cyan in Figures 1, 2A and 2B), has been shown to bind one INH molecule in the crystallographic structures of various KatG enzymes in complex with INH (NIZ-803 in Figures 2A and 2B) [17, 21-23]. Other potential INH binding sites, although remote from the heme, have been reported in various KatG enzymes, such as NIZ-802 and NIZ-804 from Synechococcus elongatus and NIZ 749 from Burkholderia pseudomallei (Figures 1 and 2B) $[24,25]$. 
At the kinetic level, KatG belongs to the class I family of peroxidases [7] and is thus capable of utilizing either hydrogen peroxide or alkyl hydroperoxides to catalyze the oxidation of various substrates, including INH, via high-valent intermediates such as the oxoferryl porphyrin $\pi$-cation radical, [KatG Por $\left.^{+} \bullet-F e I V=O\right]$ and the ferric heme coupled with a protein radical in $\mathrm{KatG}$, [KatG• Por-FeIII]) generally referred to as compounds I and II, respectively [21, 22, 26-28]. In this pathway, the two intermediate compounds I/II of KatG that are produced by oxidation of the enzyme with peroxides, can oxidize each one molecule of INH before returning to the resting state $[19,26,29,30]$. Additional pathways have been suggested to be involved in the activation process of $\mathrm{INH}$, in which the superoxide moiety, $\mathrm{O}_{2} \bullet-$, would be involved in the formation of the IN-NAD adduct from a ferric-superoxo form of KatG termed compound III ([KatG Por-FeIII- $\left.{ }_{2}{ }^{\circ}\right]$ ) [31, 32]. In $M$. tuberculosis, INH-R is mainly due to the presence of a mutation in the $k a t G$ gene leading to the replacement of Ser315 by a threonine. The substitution S315T has been previously suggested to modify the main INH binding site which is located on the edge of the narrow funnel-shaped cavity leading to the heme (corresponding to NIZ-803 in Figures 2A and 2B). In fact several hypotheses have been made from the crystallographic structure of KatG S315T [28] to explain the INHresistance of KatG S315T: a) a narrowing of the channel leading to the heme cavity conferring to the mutant KatG S315T a reduced affinity for INH, b) a reduction of water occupancy in KatG S315T which exhibits a reduced tendency to form six coordinate heme, with a less favorable binding to INH, c) an inability of oxyferrous KatG S315T to oxidize isoniazid, d) a slower turnover of INH linked to the hindrance presented by the narrower channel in Thr315, e) a disruption of the electron transfer network and f) a loss of a hydrogen bond between the side chain of S315 and a heme carboxyl group [17, 24, 28, 31-37]. The KatG mutation S315T impairs the conversion of INH to the IN-NAD adduct but preserves in part the catalase activity which is a key virulence factor in M. tuberculosis. The S315T substitution accounts for INH-R in $\sim 70 \%$ of the clinical isolates of $M$. tuberculosis $[6,8,9,38-40]$. However, in approximately 8 to $10 \%$ of the INH-R isolates, other mutations in KatG are associated with resistance by decreasing the ability of KatG to produce INH radicals, but the mechanisms by which such mutations alter the KatG activity remain partly uncharacterized.

In this study, we compare the four main enzymatic activities (catalase, peroxidase, free radical production and isonicotinoyl-NAD adduct formation) of 13 mutated proteins for which biochemical activities were never investigated, to those of the wild-type (WT) KatG enzyme of M. tuberculosis and three previously characterized KatG mutants, S315T [8, 9, 38, 39, 41, 42], A110V [38, 41, 42] and R463L [38, 41-43]. To our knowledge, 8 mutants are reported here for the first time (G118D, 
G121D, L141S, A162E, D189G, R249H, H270R, Q461), while 5 were previously described but not studied at the enzymatic level (G494D [38], R595STOP [38], F658V [38], L336P [9], W341G [38]).

\section{MATERIALS AND METHODS}

\section{Clinical isolates}

The M. tuberculosis isolates were isolated at the National Reference Centre (NRC) for Mycobacteria from TB cases diagnosed in France. They were selected on the basis of their INH-R with (i) a mutation in KatG outside codon 315 and (ii) no mutation in the other genes known to be involved in INH-R ( $f a b G 1$-inhA operon and its upstream region, furA and its upstream region, $n d h$ ), except for the KatG $\mathrm{A} 110 \mathrm{~V}$ mutant with a $-15 \mathrm{C} \rightarrow \mathrm{T}$ mutation in the $i n h A$ promoter. In this study, $k a t G, f a b G 1$-inhA operon and its upstream region, furA and its upstream region, and $n d h$ were amplified and sequenced as described before [38, 44, 45]. The mutations included S315T, A110V, G118D, G121D, L141S, A162E, D189G, R249H, H270R, L336P, W341G, Q461P, G494D, R595STOP and F658V detected in INH-R clinical isolates, and the polymorphism R463L found in INH-susceptible isolates. The isolates with KatG A110V, S315T, W341G, G494D, R595STOP, F658V and R463L are from previous studies [6, 38]. The others (G118D, G121D, L141S, A162E, D189G, R249H, H270R, L336P and Q461P) are from the NRC collection and have not been described before, except L336P [9]. Isolates with KatG G118D, L141S, R249H, H270R, L336P, Q461P, G494D, R595STOP were INH mono-resistant, while isolates with KatG A110V, G121D, A162E, D189G, S315T, W341G, F658V were mutidrug-resistant.

\section{Drug susceptibility testing}

Susceptibility testing was performed using the proportion method on Löwenstein-Jensen medium [46] at INH concentrations of 0.1, 0.2, 1 and $10 \mathrm{mg} / \mathrm{l}$. A low level of resistance was defined as resistance to $\geq 0.2$ but $<1 \mathrm{mg} / \mathrm{l}$, while a high level of resistance was defined as resistance to $\geq 1 \mathrm{mg} / \mathrm{l}$ of INH. In the present study we distinguished between isolates resistant to $\geq 1 \mathrm{mg} / \mathrm{l}$ but $<10 \mathrm{mg} / \mathrm{l}$ and isolates resistant to $\geq 10 \mathrm{mg} / 1$.

\section{Plasmid preparation}

Cloning of the $k a t G$ gene to produce hexahistidine-tagged KatG proteins. 
For KatG WT, the coding region of $k a t G$ from $\mathrm{H} 37 \mathrm{Rv}$ was amplified by PCR with the primers LIC1-katG (5'-GAC GAC GAC AAG ATG CCC GAG CAA CAC CCA CC-3') and LIC2-katG (5'-GAG GAG AAG CCC GGT TCA GCG CAC GTC GAA CCT-3') and cloned in the pET30 vector in NovaBlue GigaSingles ${ }^{\mathrm{TM}}$ competent E. coli cells using the pET-30 Ek/LIC Vector Kit (Novagen) to produce hexahistidine-tagged proteins ( $\left.\mathrm{His}_{6}-\mathrm{KatG}\right)$. To obtain resistant mutants, mutagenesis was performed according to the manufacturer's protocol using the QuikChange ${ }^{\circledR}$ sitedirected mutagenesis kit from Stratagene with the primers listed in Table 1. The mutated plasmids were introduced by transformation into XL1-Blue supercompetent $E$. coli cells. Cloning of the $k a t G$ gene to produce non-His ${ }_{6}-K_{a t G}$ proteins.

From the plasmid pET30-KatG WT, we performed site-directed mutagenesis to remove the restriction site of $N d e \mathrm{I}$ in $k a t G$ at nucleotide 75 (Table 1). After PCR amplification of the $k a t G$ gene with a primer containing the restriction site for NdeI and the 5' end of katG (primer KatGNdeI : 5'CAT ATG CCC GAG CAA CAC C-3' ) and a primer containing the restriction site for HindIII and the 3' end of katG (primer KatGHindIII : 5'-AAG CTT TCA GCG CAC GTC G-3'), subcloning of the amplified product in TOPO was achieved with the TOPO TA cloning ${ }^{\circledR}$ kit (Invitrogen). Then, the plasmid $\mathrm{pCR}^{\circledR}$ 2.1-TOPO ${ }^{\circledR}-\mathrm{KatG}$ was digested with $N d e \mathrm{I}$ and HindIII, and the digestion product cloned into pET29 digested with the same enzymes. The ligation product was introduced into TOP10 E. coli cells by electroporation.

XL1-Blue (for His $_{6}-\mathrm{KatG}$ ) or TOP-10 (for non-His ${ }_{6}-\mathrm{KatG}$ ) Escherichia coli cells with plasmids pET30-katG and pET29-katG, respectively, were grown on Luria Bertani (LB) agar plates containing $30 \mu \mathrm{g} / \mathrm{ml}(30 \gamma)$ kanamycin. Liquid cultures of LB-kanamycin $30 \gamma$ were inoculated with individual colonies, grown overnight at $37^{\circ} \mathrm{C}$ and the bacteria pelleted by centrifugation. Plasmid DNA was extracted and purified from the bacterial pellet using the QIAprep Spin Miniprep ${ }^{\circledR}$ kit (Qiagen). Sequencing of double-stranded plasmid DNA was used to confirm the desired nucleotide substitutions and the absence of secondary mutations.

\section{Production of the KatG proteins}

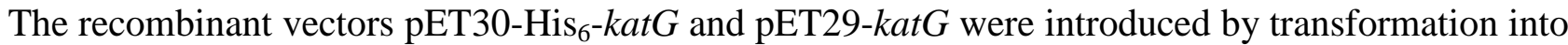
BL-21(DE3)pLysS E. coli cells (Stratagene) and the cells plated onto LB-kanamycin 30 $\gamma$ plates and grown overnight at $37^{\circ} \mathrm{C}[31,32]$. Starter cultures (LB-kanamycin $30 \gamma ; 4 \mathrm{ml}$ each) were inoculated with a single colony and grown to an optical density of $0.5-1$. Each starter culture was further used to inoculate $50 \mathrm{ml}$ of LB medium containing $30 \mathrm{mg} / \mathrm{l}$ hemin (dissolved in $0.2 \mathrm{~N} \mathrm{NaOH}$ ) and $30 \gamma$ kanamycin. The addition of hemin ensures stoichiometric incorporation of the heme cofactor during 
overexpression in E. coli for maximal holoenzyme isolation [47]. For BL21 cells with pET29-katG, additional cultures were used to inoculate $500 \mathrm{ml}$ of the same LB medium. Expression of the cloned genes was then induced with isopropyl $\beta$-D-1-thiogalactopyranoside ( $1 \mathrm{mM}$ final concentration) and the cultures were grown overnight at $18^{\circ} \mathrm{C}$. After centrifugation, the cell pellet was resuspended and lysed by sonication in an ice bucket. Cellular debris was pelleted at 18,000 x $g$ for 60 min, resulting in a viscous, red-brown crude extract (except for the H270R mutant that had no color).

\section{Purification of the catalase/peroxidase KatG}

Hexahistidine-tagged KatG.

KatG proteins were purified from the crude extracts using the Ni-NTA His-Bind ${ }^{\circledR}$ resin and the His·Bind ${ }^{\circledR}$ Buffer Kit from Novagen, following the manufacturer's instructions.

Non-hexahistidine-tagged KatG

Nucleic acids were precipitated by the addition of spermine $(1 \% \mathrm{w} / \mathrm{v}$, final concentration) to the supernatant (15 min in ice), and the solution was centrifuged for $1 \mathrm{hr}$ at 48,000 x $g$ to pellet the nucleic acids. Dialysis against $20 \mathrm{mM}$ Bis Tris, $\mathrm{pH}$ 6.0, was carried out overnight and the dialysate filtered (pore size, $0.22 \mu \mathrm{m}$ ). The clear supernatant was applied to a Q-Sepharose HiTrap ${ }^{\mathrm{TM}} \mathrm{Q}$ HP 5 $\mathrm{ml}$ (GE Healthcare Life Sciences) column equilibrated with $20 \mathrm{mM}$ Bis Tris, pH 6.0. The adsorbed proteins were eluted using a linear 0 to $1-\mathrm{M} \mathrm{NaCl}$ gradient. Fractions containing catalase activity, which eluted between 0.3 and $0.4 \mathrm{M} \mathrm{NaCl}$, were pooled, dialyzed at $4^{\circ} \mathrm{C}$ overnight against $20 \mathrm{mM}$ Bis Tris, pH 6.0, and applied to a DEAE-Sepharose (GE Healthcare Life Sciences) anion-exchange column equilibrated with Bis Tris $20 \mathrm{mM}, \mathrm{pH}$ 6.0. The adsorbed proteins were eluted using a linear 0 to $1-\mathrm{M} \mathrm{NaCl}$ gradient. The active fractions were pooled, concentrated on Amicon ${ }^{\circledR}$ Ultra filters (Millipore) and subjected to gel filtration on a Superdex ${ }^{\mathrm{TM}} 200$ (GE Healthcare Life Sciences) column in $20 \mathrm{mM}$ Bis Tris, $50 \mathrm{mM} \mathrm{NaCl}$, pH 6.0 [11, 26, 48].

\section{In-vitro KatG enzymatic activities}

Protein concentration was determined using the heme extinction coefficient $\varepsilon_{407 \mathrm{~nm}}=100 \mathrm{mM}^{-1} \mathrm{~cm}^{-1}$ [28], except for the H270R mutant that contained no heme and for which the protein concentration was determined using the Bradford method with a Nanodrop ${ }^{\circledR}$ spectrophotometer (Thermo Scientific). All assays were performed in triplicate.

The catalase activity was determined spectrophotometrically by measuring the decrease in $\mathrm{H}_{2} \mathrm{O}_{2}$ concentration at $240 \mathrm{~nm}\left(\varepsilon_{240 \mathrm{~nm}}=0.0435 \mathrm{mM}^{-1} \mathrm{~cm}^{-1}\right)$. The reaction mixture contained $50 \mathrm{mM}$ sodium phosphate buffer, $\mathrm{pH} 7.5,25 \mathrm{mM} \mathrm{H}_{2} \mathrm{O}_{2}$ and $30 \mathrm{nM} \mathrm{KatG}$ (up to $2 \mu \mathrm{M}$ for mutants with low 
catalase activity) $[48,49]$. One unit (U) of catalase activity corresponded to the consumption of 1 $\mu$ mole $\mathrm{H}_{2} \mathrm{O}_{2} / \mathrm{min} / \mathrm{mg}$ of protein. The apparent $K_{\mathrm{m}}$ and $k_{\text {cat }}$ values were obtained from non-linear regression of Michaelis-Menten [32].

The peroxidase activity was determined spectrophotometrically by measuring the rate of oxidation of $0.1 \mathrm{mM} O$-dianisidine, at $460 \mathrm{~nm}\left(\varepsilon_{460 \mathrm{~nm}}=11.3 \mathrm{mM}^{-1} \mathrm{~cm}^{-1}\right)$ in the presence of $23 \mathrm{mM}$ tert-butyl hydroperoxide (tBHP) in $50 \mathrm{mM}$ sodium acetate buffer, $\mathrm{pH} 5.5$ and $100 \mathrm{nM}$ KatG (up to $2 \mu \mathrm{M}$ for KatG H270R) [48, 50]. One $\mathrm{U}$ of peroxidase activity was defined as the oxidation of 1 mmole $O$ dianisidine/min/mg of protein.

The free radical production was followed at $560 \mathrm{~nm}$ using the INH-dependent reduction of nitroblue tetrazolium (NBT) to mono- and diformazan $\left(\varepsilon_{560 \mathrm{~nm}}=15,000 \mathrm{M}^{-1} \mathrm{~cm}^{-1}\right.$ for monoformazan $)[49,50]$. The reaction mixture consisted of $0.2 \mathrm{mM}$ NBT in $50 \mathrm{mM}$ Tris $\mathrm{HCl}$ buffer ( $\mathrm{pH}$ 8.5) containing INH (7.5 mM) and enzyme ( $30 \mathrm{nM}$, or up to $2 \mu \mathrm{M}$ for $\mathrm{KatG} \mathrm{H} 270 \mathrm{R})$. The reactions were initiated by the addition of $\mathrm{H}_{2} \mathrm{O}_{2}(500 \mu \mathrm{M})$. One $\mathrm{U}$ of free radical production activity was defined as $1 \mathrm{nmole}$ NBT reduced to monoformazan $/ \mathrm{min} / \mathrm{nmole}$ of heme.

The rate of isonicotinoyl-NAD (IN-NAD) adduct formation was determined spectrophotometrically at $326 \mathrm{~nm}$ using the extinction coefficient of isonicotinoyl-NAD $\left(\varepsilon_{326 \mathrm{~nm}}=6.900 \mathrm{M}^{-1} \mathrm{~cm}^{-1}\right)[13,28$, $31,50-52]$. The reaction was carried out using KatG $(2 \mu \mathrm{M}), \mathrm{NAD}+(240 \mu \mathrm{M})$, the $\mathrm{H}_{2} \mathrm{O}_{2}$-generating system glucose/glucose oxidase (G/Gox) [glucose oxidase (66.6 mU/mL), glucose (16.7 mM)] [31] and INH $(200 \mu \mathrm{M})$ in $50 \mathrm{mM}$ sodium phosphate, $\mathrm{pH} 7.5)$. The reference cuvette contained all components except $\mathrm{NAD}^{+}$to correct for background activity, as previously described [28, 37]. The generation of adduct was initiated by the addition of INH $(200 \mu \mathrm{M})$. One U of isonicotinoyl-NAD formation activity was defined as the production of $1 \mathrm{nmole}$ isonicotinoyl-NAD/min/nmole of heme.

\section{Three-dimensional modeling}

The location of the mutations detected in KatG was investigated using the crystal structure of the $M$. tuberculosis KatG protein (PDB entry 2CCA) [28] with PyMol software [53].

\section{Nucleotide sequence accession numbers.}

The nucleotide sequences determined for the kat $G$ mutants were deposited in the GenBank database under accession numbers KC122363 to KC122378. 


\section{RESULTS}

\section{Purification of KatG proteins}

In this study, two non-His ${ }_{6}-\mathrm{KatG}$ proteins (KatG WT and the S315T mutant) and $17 \mathrm{His}_{6}-\mathrm{KatG}$ proteins (KatG WT, the S315T mutant, the polymorphism R463L mutant, and 14 other KatG mutants) were produced. The His ${ }_{6}$-tag was introduced to facilitate the purification of the protein by nickel affinity chromatography, and the two non-His 6 -KatG proteins, KatG WT and the S315T mutant, were purified in order to verify that the presence of the His 6 -tag did not alter the biochemical and the enzymatic properties of KatG. The two non-tagged proteins had an optical purity ratio (Reinheitszahl: $\mathrm{Rz}$ ) (heme Soret absorbance/total protein absorbance: $\mathrm{A}_{408} / \mathrm{A}_{280}$ ) [54] of 0.58 and 0.55 , respectively and were obtained with typical yields of $\sim 6 \mathrm{mg}$ per liter of culture. They displayed a single band of $\sim 80,000$ daltons on SDS-PAGE, and of $\sim 160,000$ daltons on nondenaturing PAGE (data not shown). The $\mathrm{His}_{6}$-KatG proteins were purified using immobilized metal affinity chromatography which yielded brown protein solutions with an Rz $>0.5$, except for the colorless KatG H270R mutant for which $\mathrm{Rz}$ was $<0.01$. The typical yield of purified protein was $\sim 25 \mathrm{mg}$ per $100 \mathrm{ml}$ of culture, except for the two mutants R595STOP and Q461P for which $2 \mathrm{mg}$ of protein were obtained. All mutant proteins had an apparent molecular weight of $\sim 80,000$ daltons on SDS-PAGE, except R595STOP with 65,000 daltons (data not shown).

\section{Enzymatic activities}

Before studying the enzymatic activities of the KatG mutants, we tested whether the $\mathrm{His}_{6}$-tag introduced to facilitate the purification of the proteins affected these activities. The $K_{\mathrm{m}}$ and $k_{\text {cat }}$ values for catalase activity of $\mathrm{His}_{6}$-KatG WT were nearly identical to those of non-tagged KatG WT ( $\sim 10 \mathrm{mM}$ and $\sim 4.000 \mathrm{~s}^{-1}$, respectively). These values were in accordance with previously reported values, ranging from 0.6 to $30 \mathrm{mM}$ and from 2,300 to $10,000 \mathrm{~s}^{-1}$, respectively $[11,31,32,48,49$, 54-56]. We also comparatively assayed for the WT and the S315T mutant the catalase and peroxidase activities, free radical production and IN-NAD adduct formation of the $\mathrm{His}_{6^{-}}$and nonHis $_{6}$-KatG proteins which yielded very similar values (Table 2).

The catalase activity of the $\mathrm{His}_{6}$-KatG WT enzyme was $2023 \pm 58 \mathrm{U}$ and its peroxidase activity was $0.91 \pm 0.03 \mathrm{U}$. As for free radical production (NBT reduction), we noted a significant background activity of NBT reduction in the absence of isoniazid with the WT enzyme. However, NBT reduction was substantially enhanced in the presence of isoniazid, allowing us to determine after subtraction of the background activity $[43,56]$ the net INH-dependent reduction of NBT (free 
radical production) which was $2.01 \pm 0.15 \mathrm{U}$ (Table 2). Finally, isonicotinoyl-NAD adduct formation in the absence of $\mathrm{KatG}$ was undetectable with the $\mathrm{H}_{2} \mathrm{O}_{2}$-generating G/Gox system (data not shown) [31]. This adduct formation by $\mathrm{His}_{6}-\mathrm{KatG}$ WT was $0.78 \pm 0.02$, consistent with previously reported values $[33,37,50,57]$.

Fifteen KatG mutants from INH-R clinical isolates and the R463L mutant found in INH-susceptible clinical isolates (R463L is a phenotypically silent polymorphism) were studied comparatively to the WT enzyme (Table 2). As mentioned above, 8 have never been reported before (G118D, G121D, L141S, A162E, D189G, R249H, H270R, Q461), 5 were previously described but not studied (G494D [38], R595STOP [38], F658V [38], L336P [9], W341G [38]) and 3 were reported and their biochemical activities were investigated (S315T [8, 9, 38, 39, 41, 42], A110V [38, 41, 42], R463L [38, 41-43]). Here we report their enzymatic activities relative to those of KatG WT. The 16 KatG mutants could be categorized into six distinct groups based on the activity profiles given in Table 2. First, H270R, which was purified from a very high-level INH-R clinical isolate, was the only mutant for which no enzymatic activity was detectable (Table 2). The second group included five mutants (R595STOP, L336P, W341G, G118D, L141S) obtained from very high-level INH-R isolates and one mutant (G121D) from a high-level INH-R isolate. Overall, the six mutants were characterized by a drastic decrease in their enzymatic activities. Catalase activity was virtually undetectable in four (R595STOP, L336P, W341G and G118D), while the remaining two mutants (G121D and L141S) had very low residual activity (i.e. 14 and 2\% of the KatG WT activity, respectively) (Table 2). Concomitantly, the six mutants displayed a marked alteration of free radical production activity, with values ranging from 7 to $19 \%$ (Table 2). On the other hand, the mutants, which were all impaired in their peroxidase activity and their capacity to form IN-NAD adducts, retained significant residual activities ranging from 21 to $45 \%$ for the peroxidase activity, and from 12 to $41 \%$ for the IN-NAD formation (Table 2).

The third group included two mutants, S315T and A162E, from high-level and very high-level INH-R isolates, respectively. Both were characterized by a sharp decrease in free radical production efficiency (residual activities of 9 and 26\%, respectively) but were only moderately affected in their catalase and peroxidase activities (55 and $70 \%$ and 70 and 118\%, respectively). S315T displayed a drastic decrease in IN-NAD formation activity (10\%), while A162E appeared to be less affected $(56 \%)$.

Five mutants were included in the fourth group. One of them (G494D) was identified in a high-level INH-R isolate, and four (Q461P, D189G, R249H, and F658V) were found in low-level INH-R isolates (Table 2). Overall, these five mutants showed moderately impaired enzymatic activities 
when compared to the abovementioned mutants, with values ranging from 43 to $83 \%$ for catalase activity, 45 to $88 \%$ for free radical production, 72 to $109 \%$ for peroxidase activity, and 60 to $78 \%$ for IN-NAD formation (Table 2).

KatG mutant A110V was considered to form a group of its own because it showed moderately decreased catalase and free radical production activities (71 and 73\%, respectively) while its peroxidase activity was markedly increased (198\% compared to KatG WT). This mutant was obtained from a low-level INH-R isolate (Table 2).

Finally, mutant R463L, obtained from an INH-susceptible clinical isolate, represented a phenotypically silent polymorphism that can be found in INH-susceptible and INH-R isolates [38, 55]. When compared to KatG WT, R463L showed no variation in free radical production and the three other activities were only slightly lower (Table 2 ).

\section{DISCUSSION}

Analysis of the enzymatic parameters allowed the distinction of several categories of mutants that are discussed below (Table 3).

\section{Mutants with no detectable enzymatic activity}

All enzymatic activities of the KatG mutant H270R found in a very high-level INH-R isolate were abolished. The histidine residue at position 270 of KatG WT is located in the proximal pocket and forms an essential link of coordination with the iron of the heme (Figure, 2A). In the H270R protein, the mutation creates a steric hindrance and causes loss of the coordination link to the heme. Consequently, the heme cannot bind to KatG, as demonstrated by the Rz value $<0.01$ found for the purified H270R protein. This heme defect in KatG accounts for the complete loss of enzymatic activity of the H270R mutant.

\section{Mutants with drastically decreased catalase and free radical production activities}

The KatG R595STOP mutation, associated with a very high level of INH-R, creates a truncated protein in which 145 amino acid residues are deleted in the C-terminal domain (shown in orange in Figure 1). The yield of purification of the $\mathrm{His}_{6}$-KatG R595STOP protein was lower than those obtained for the other proteins ( $2 \mathrm{mg}$ versus $25 \mathrm{mg}$, respectively), indicating that the folding and/or the stability of the C-terminally truncated protein could be markedly altered. Nevertheless, the Rz value of $>0.5$ indicated that there is no alteration of heme binding in the active site. The catalase 
activity of the R595STOP mutant was completely abolished, showing that the C-terminal region is important for this activity, even if it is generally considered to make no direct contribution to the catalytic mechanism [58]. By contrast, this mutant exhibited drastically reduced but still measurable peroxidase, free radical production and IN-NAD formation activities (Table 2), indicating that secondary oxido-reduction pathways decoupled from the catalase mechanism are still functional in the mutant protein, as previously suggested $[11,17,31,55]$.

The two mutants W341G and L336P were characterized by undetectable catalase activity and drastically reduced free-radical production activity (Table 2). They also displayed significant reduction in their peroxidase and IN-NAD formation activities. The two residues are located in the proximal pocket in the vicinity of Met377 (mean distance of $\sim 4.1 \AA$ ) (Figure $2 \mathrm{~A}$ ) which is at $3.9 \AA$ to Trp321 in the essential triad His270, Trp321, Asp381 (Figure 2A). Previous studies have shown that mutations in the 3 latter amino acids of the proximal triad of KatG in different bacteria are generally shown to be responsible for less than $0.1 \%$ catalase activity compared to the WT enzyme $[42,59]$. In the 2 mutants $\mathrm{W} 341 \mathrm{G}$ and L336P, which are both drastically affected in their catalase activity, the replacement of Trp341 by a glycine creates a cavity exposing Met377 to the solvent, while the introduction of a proline at position 336 probably alters the folding of the alpha-helix holding this residue and generates more room around Met377. As a consequence, both mutations induce critical structural alterations in a region essential for the catalase activity of KatG and the formation of compound $\mathrm{I}\left[\mathrm{KatG}\right.$ Por $\left.^{+} \cdot \mathrm{FeIV}=\mathrm{O}\right]$ required for the oxidation of INH to IN•.

G118D and G121D are above the distal pocket containing the essential catalytic residue His108 (Figure 2B). Both mutants were associated with high to very high levels of INH-R and had very similar enzymatic properties with a dramatic decrease in catalase and free radical production activities (Table 2). In the 3D structure of KatG, Gly118 and Gly121 are localized at the solventexposed face of a long tunnel constituting the back door entrance of the distal pocket connecting the catalytic residue His108 to the outside of the protein, which contains an extended network of hydrogen-bonded water molecules and could be an equivalent of the access channel of $\mathrm{H}_{2} \mathrm{O}_{2}$ in the mono-functional catalases (Figure 2B). In both mutants, the replacement of Gly118 and Gly121 by an aspartic acid could disrupt the integrity of this channel by creating steric clashes and possibly electrostatic interactions with the side chains of two neighbouring arginine residues, Arg484 (with Asp118) and Arg418 (with Asp121) (Figure 2B), the latter acting like a catalytic switch that can be oriented toward the solvent or toward the essential Met255-Tyr229-Trp107 triad (see the two orientations in Figure 2B) [60]. One can note that G118D and G121D mutants maintained a significant level of peroxidase activity, while the catalase activity was very low (Table 2), 
suggesting that oxidation of the heme by tBHP involves oxydo-reduction pathways distinct from those involved during $\mathrm{H}_{2} \mathrm{O}_{2}$ oxidation.

The L141S mutant, which was detected in a very high-level INH-R isolate, displays an extremely low level of catalase activity and a drastic reduction of free radical and IN-NAD production. Leu141 is located next to the distal pocket at a close distance $(3.8 \AA)$ to the ring of the key catalytic residue His108 (Figure 2B). It is therefore likely that Leu141 prevents the side chain of His 108 to move away from the iron atom and the Trp107-Tyr229-Met255 triad which participates in the stabilization of the radical formed after initial oxidation by $\mathrm{H}_{2} \mathrm{O}_{2}$. The replacement of Leu141 by a serine not only creates room allowing His108 to shift from its optimal position, but also introduces a polar side chain in the heme region that may disturb the electron transfer pathways required for the catalase activity. Of note is the fact that the mutant displayed a significant level of peroxidase activity like the other mutants described above.

\section{Mutants with drastically decreased free radical production activity but retaining significant catalase/peroxidase activity}

Mutants S315T and A162E, which were respectively found in isolates with high- and very highlevels of INH-R displayed a unique enzymatic behaviour in the sense that there is a marked decoupling in both mutants between the catalase and peroxidase activities, which decreased slightly, and the activities of IN p production and formation of the IN-NAD adduct which decreased sharply (Table 2).

$\mathrm{S} 315 \mathrm{~T}$, which is the most commonly occurring mutation in clinical isolates (found in $\sim 70 \%$ of INH$\mathrm{R}$ isolates), has been extensively studied in the past. In concordance with previous reports [28, 31, $32,41,49,54]$, we observed that S315T showed a moderate reduction in catalase and peroxidase activities, contrasting with the dramatic reduction in IN• and IN-NAD formation activities (Table 2), indicating that S315T specifically affects the binding and/or processing of INH. Accordingly, $\mathrm{S} 315 \mathrm{~T}$ is located in the immediate vicinity of the heme, in the narrowest part of a short funnelshaped channel connecting the heme pocket filled with water molecules (in cyan on Figure 2B) to the outside of the protein. This channel has been previously suggested to contain the primary INH biding site (NIZ-803 on Figure 2B) and the bulkier side chain of Thr315 would impede the access of INH to the heme pocket [28]. This model readily explains the decoupling of the effects observed for the catalase/peroxidase activities on one hand, which are in part preserved, and the loss of activation of INH on the other. However, one has to note here that alternative hypotheses have been 
proposed which relate the Ser315 mutation to structural alterations affecting the porphyrin moiety and the electron transfer processes (as detailed in the Introduction section) [17, 24, 28, 31-37].

The behaviour of the A162E mutant is more puzzling. In the structure of KatG, Ala162 is located at the N-terminal part of an alpha-helix, at a very long distance to the heme pocket (Figure 2B). The side chain of Glu162, which lies very close to the solvent-exposed face of the long tunnel leading to the distal pocket, creates steric clashes with nearby residues, in particular Gly123 and Gly124 located downstream of Gly118-Gly121. It is therefore conceivable that the mutation A162E decreases the rate of free radical production (Table 2), as observed in the 2 mutants G118D and G121D. On the other hand, the limited effects observed on the catalase and peroxidase activities, are more difficult to explain.

\section{Mutants showing moderately decreased enzymatic activities}

We studied five mutants (G494D, Q461P, D189G, R249H, and F658V) that were associated with low-level of INH-R (except G494D found in a high-level resistant isolate) and that had similar catalytic effects, i.e. a moderate (G494D, Q461P and D189G) to weak (R249H and F658V) overall reduction of all measured activities that decreased within the range of 6 to 57\% (Table 2). In the KatG structure, the mutated residues are remote from the heme active site, except $\mathrm{R} 249 \mathrm{H}$ which is found in the middle of an alpha-helix located at the edge of the heme pocket (Figure 1). Despite its critical position with respect to the heme, the replacement of Arg249 by an histidine has limited impact on the enzymatic activities of KatG (Table 2), probably because the corresponding side chain is oriented toward the solvent (Figure 1). The four remaining mutations, G494D, Q461P, D189G and F658V are distant from the heme pocket, G494D, Q461P and F658V being located in the C-terminal domain of KatG (Figure 1). Interestingly, the purification yield of the Q461P mutant was significantly lower when compared to that of the other proteins ( $2 \mathrm{mg}$ versus ca $25 \mathrm{mg}$, respectively), suggesting that the introduction of a proline at position 461 significantly impairs the folding and/or the stability of KatG. In contrast, the replacements in the 3 remaining mutants did not modify the purification yield or the $\mathrm{Rz}$ value. Nevertheless, the mutations gave rise to an overall impairment of the enzymatic activities (by 50\%) which may be ascribed to steric effects (F658V) and/or to modifications of ionic and polar contacts with neighboring residues (G494D and D189G).

\section{Mutants displaying a moderate effect on catalase and INH activation, with an increased peroxidase activity}


The A110V mutant was obtained from a low-level INH-R isolate, which also harboured a $-15 \mathrm{C} \rightarrow \mathrm{T}$ mutation in the inhA promoter known to confer a low-level of INH-R. It is therefore difficult to establish the contribution of the KatG A110V mutation in the INH-R of this isolate [6, 7]. The residue Ala110 is located at the level of the heme pocket, not far from the catalytic residue His108 and the Trp107 of the Met255-Tyr229-Trp107 adduct (Figure 2B). Although inexplicable at the molecular level at the present state of our knowledge, our kinetic results are consistent with published observations $[17,40,56]$ and confirm that the bulkier side chain of Val110 restricts the degree of freedom of the helix bearing His108, which moderately reduces the catalase and the IN• and IN-NAD formation activities (Table 2), but increases by 2 fold the peroxidase activity compared to that of WT KatG. Additionally, they confirm that there is decoupling of enzymatic functions in KatG.

\section{Mutants that do not modify the free radical production activity and do not confer INH-R}

The R463L mutation is frequently detected in INH-susceptible isolates. The residue is located far away from the porphyrin ring (56 $\AA$ ) (Figure 1). As shown by our enzymatic measurements, this mutation has a very limited impact on the four enzymatic activities (Table 2). These results are consistent with published data and with the view that this mutation is an instance of a phenotypically silent polymorphism $[31,41,54,55]$.

\section{CONCLUSION}

Considering the current state of our knowledge, reaching a comprehensive understanding of the role of KatG mutations in the enzymatic perturbations observed in KatG remains a demanding task. Concluding from the observations made with the mutations identified in high-level INH-R isolates (Table 3), 7 mutants from very high-level (H270R, R595STOP, L336P, W341G, G118D, and L141S) or high-level (G121D) INH-R showed a drastic decrease in their catalase activity, resulting in the impairment of compound I [KatG Por $\left.^{+} \cdot-\mathrm{FeIV}=\mathrm{O}\right]$ formation in the presence of hydrogen peroxide. As a consequence, the rate of $\mathrm{IN}$ - production in the presence of $\mathrm{H}_{2} \mathrm{O}_{2}$ (i.e. free radical production), which requires the formation of compound I, is dramatically affected when catalase activity is lost. However, one can note that these mutants generally retained significant peroxidase activity, an observation which sustains the hypothesis that oxidation of the heme in KatG would occur through two distinct routes according to the type of oxidizing molecule used in the reaction, i.e. the $\mathrm{H}_{2} \mathrm{O}_{2}$ pathway on one hand and the alkyl peroxide pathway (tBHP in this study) on the 
other. Two other mutants from high- or very high-level INH-R isolates (S315T and A162E, respectively) exhibited an optimal balance between drastic decrease in free radical production and relative conservation of catalase and peroxidase activities, a property that may confer a survival advantage to the bacterial cell and that has been suggested previously to account for the global spread of isolates with the KatG S315T mutation [61]. Conversely, the mutants associated with low-level of INH-R, such as Q461P, D189G, R249H and F658V, were generally characterized by a moderate reduction in the four catalytic activities. Finally, it is worth highlighting that there was no strict correlation between the level of INH-R and the IN-NAD activities of the KatG mutants in our study, in accordance with previous reports [31]. However, the mutants from high- (HL1) to very high-level (HL10) INH-R isolates displayed relative activities below 50\%, while those from lowlevel resistant isolates had relative activities above that value (Table 2).

\section{ACKNOWLEDGMENTS}

We gratefully acknowledge Nicolas Veziris who provided us with the isolates and Anabella Ivancich for helpful discussions. We thank Ekkehard Collatz for English editing.

\section{COMPETING INTERESTS}

None declared.

\section{FUNDING}

This work was supported by grants from the Institut National de la Santé et de la Recherche Médicale (INSERM) and the Université Pierre et Marie Curie (UPMC).

\section{ETHICAL APPROVAL}

Not required. 


\section{REFERENCES}

[1] Zhang Y, Heym B, Allen B, Young D, Cole S. The catalase peroxidase gene and isoniazid resistance of Mycobacterium tuberculosis. Nature 1992;358:591-3.

[2] Johnsson K, Schultz PG. Mechanistic studies of the oxidation of isoniazid by the catalase peroxidase from Mycobacterium tuberculosis. J Am Chem Soc 1994;116:7425-6.

[3] Banerjee A, Dubnau E, Quemard A, Balasubramanian V, Um KS, Wilson T, et al. inhA, a gene encoding a target for isoniazid and ethionamide in Mycobacterium tuberculosis. Science 1994;263:227-30.

[4] Marrakchi H, Laneelle G, Quemard A. InhA, a target of the antituberculous drug isoniazid, is involved in a mycobacterial fatty acid elongation system, FAS-II. Microbiology 2000;146:289-96.

[5] Vilchèze C, Wang F, Arai M, Hazbon MH, Colangeli R, Kremer L, et al. Transfer of a point mutation in Mycobacterium tuberculosis inhA resolves the target of isoniazid. Nat Med 2006;12:1027-9.

[6] Brossier F, Veziris N, Jarlier V, Sougakoff W. Performance of MTBDR plus for detecting high/low levels of Mycobacterium tuberculosis resistance to isoniazid. Int $\mathbf{J}$ Tuberc Lung Dis 2009;13:260-5.

[7] Larsen MH, Vilcheze C, Kremer L, Besra GS, Parsons L, Salfinger M, et al. Overexpression of inhA, but not kasA, confers resistance to isoniazid and ethionamide in Mycobacterium smegmatis, M. bovis BCG and M. tuberculosis. Mol Microbiol 2002;46:453-66.

[8] Hazbón MH, Brimacombe M, Bobadilla del Valle M, Cavatore M, Guerrero MI, VarmaBasil M, et al. Population genetics study of isoniazid resistance mutations and evolution of multidrug-resistant Mycobacterium tuberculosis. Antimicrob Agents Chemother 2006;50:2640-9.

[9] Ramaswamy SV, Reich R, Dou SJ, Jasperse L, Pan X, Wanger A, et al. Single nucleotide polymorphisms in genes associated with isoniazid resistance in Mycobacterium tuberculosis. Antimicrob Agents Chemother 2003;47:1241-50.

[10] Zhang Y. Isoniazid. In: Rom WN, Garay SM, editors. Tuberculosis. 2nd ed. Philadelphia, PA, USA: Lippincott Williams and Wilkins; 2004, p. 739-758.

[11] Nagy JM, Cass AE, Brown KA. Purification and characterization of recombinant catalaseperoxidase, which confers isoniazid sensitivity in Mycobacterium tuberculosis. J Biol Chem 1997;272:31265-71. 
[12] Welinder KG. Bacterial catalase-peroxidases are gene duplicated members of the plant peroxidase superfamily. Biochim Biophys Acta 1991;1080:215-20.

[13] Lei B, Wei CJ, Tu SC. Action mechanism of antitubercular isoniazid. Activation by Mycobacterium tuberculosis KatG, isolation, and characterization of InhA inhibitor. J Biol Chem 2000;275:2520-6.

[14] Quémard A, Sacchettini JC, Dessen A, Vilcheze C, Bittman R, Jacobs WR Jr, et al. Enzymatic characterization of the target for isoniazid in Mycobacterium tuberculosis. Biochemistry 1995;34:8235-41.

[15] Rozwarski DA, Grant GA, Barton DH, Jacobs WR Jr, Sacchettini JC. Modification of the $\mathrm{NADH}$ of the isoniazid target (InhA) from Mycobacterium tuberculosis. Science 1998;279:98-102.

[16] Vilchèze C, Jacobs WR Jr. The mechanism of isoniazid killing: clarity through the scope of genetics. Annu Rev Microbiol 2007;61:35-50.

[17] Bertrand T, Eady NA, Jones JN, Jesmin, Nagy JM, Jamart-Grégoire B, et al. Crystal structure of Mycobacterium tuberculosis catalase-peroxidase. J Biol Chem 2004;279:389919.

[18] Carpena X, Loprasert S, Mongkolsuk S, Switala J, Loewen PC, Fita I. Catalase-peroxidase KatG of Burkholderia pseudomallei at 1.7 Å resolution. J Mol Biol 2003;327:475-89.

[19] Ghiladi RA, Knudsen GM, Medzihradszky KF, Ortiz de Montellano PR. The Met-Tyr-Trp cross-link in Mycobacterium tuberculosis catalase-peroxidase (KatG): autocatalytic formation and effect on enzyme catalysis and spectroscopic properties. J. Biol Chem 2005;280:22651-63.

[20] Yamada Y, Fujiwara T, Sato T, Igarashi N, Tanaka N. The $2.0 \AA$ crystal structure of catalase-peroxidase from Haloarcula marismortui. Nat Struct Biol 2002;9:691-5.

[21] Metcalfe C, Macdonald IK, Murphy EJ, Brown KA, Raven EL, Moody PC. The tuberculosis prodrug isoniazid bound to activating peroxidases. J Biol Chem 2008;283:6193-200.

[22] Pierattelli R, Banci L, Eady NA, Bodiguel J, Jones JN, Moody PC, et al. Enzyme-catalyzed mechanism of isoniazid activation in class I and class III peroxidases. J Biol Chem 2004;279:39000-9.

[23] Singh AK, Kumar RP, Pandey N, Singh N, Sinha M, Bhushan A, et al. Mode of binding of the tuberculosis prodrug isoniazid to heme peroxidases: binding studies and crystal structure of bovine lactoperoxidase with isoniazid at $2.7 \AA$ resolution. J Biol Chem 2010; 285:156976. 
[24] Wiseman B, Carpena X, Feliz M, Donald LJ, Pons M, Fita I, et al. Isonicotinic acid hydrazide conversion to isonicotinyl-NAD by catalase-peroxidases. $\mathrm{J}$ Biol Chem 2010;285:26662-73.

[25] Kamachi S, Hirabayashi K, Tamoi M, Shigeoka S, Tada T, Wada K. The crystal structure of isoniazid-bound KatG catalase-peroxidase from Synechococcus elongatus PCC7942. FEBS J 2015;282:54-64.

[26] Chouchane S, Lippai I, Magliozzo RS. Catalase-peroxidase (Mycobacterium tuberculosis $\mathrm{KatG})$ catalysis and isoniazid activation. Biochemistry 2000 ; 39:9975-83.

[27] Magliozzo RS, Marcinkevieciene JA. Evidence for isoniazid oxidation by oxyferrous mycobacterial catalase-peroxidase. J Am Chem Soc 1996;118:11303-4.

[28] Zhao X, Yu H, Yu S, Wang F, Sacchettini JC, Magliozzo RS. Hydrogen peroxide-mediated isoniazid activation catalyzed by Mycobacterium tuberculosis catalase-peroxidase (KatG) and its S315T mutant. Biochemistry 2006;45:4131-40.

[29] Ghiladi RA, Medzihradszky KF, Ortiz de Montellano PR. Role of the Met-Tyr-Trp crosslink in Mycobacterium tuberculosis catalase-peroxidase (KatG) as revealed by KatG(M255I). Biochemistry 2005;44:15093-105.

[30] Jakopitsch C, Droghetti E, Schmuckenschlager F, Furtmüller PG, Smulevich G, Obinger C. Role of the main access channel of catalase-peroxidase in catalysis. J Biol Chem 2005;280:42411-22.

[31] Cade CE, Dlouhy AC, Medzihradszky KF, Salas-Castillo SP, Ghiladi RA. Isoniazidresistance conferring mutations in Mycobacterium tuberculosis KatG: catalase, peroxidase, and INH-NADH adduct formation activities. Protein Sci 2010;19:458-74.

[32] Ghiladi RA, Medzihradszky KF, Rusnak FM, Ortiz de Montellano PR. Correlation between isoniazid resistance and superoxide reactivity in Mycobacterium tuberculosis KatG. J Am Chem Soc 2005;127:13428-42.

[33] Yu S, Girotto S, Lee C, Magliozzo RS. Reduced affinity for isoniazid in the S315T mutant of Mycobacterium tuberculosis KatG is a key factor in antibiotic resistance. J Biol Chem 2003;278:14769-75.

[34] Kapetanaki SM, Chouchane S, Girotto S, Yu S, Magliozzo RS, Schelvis JP. Conformational differences in Mycobacterium tuberculosis catalase-peroxidase KatG and its S315T mutant revealed by resonance raman spectroscopy. Biochemistry 2003;42:3835-45. 
[35] Deemagarn T, Wiseman B, Carpena X, Ivancich A, Fita I, Loewen PC. Two alternative substrate paths for compound I formation and reduction in catalase-peroxidase KatG from Burkholderia pseudomallei. Proteins 2007;66:219-28.

[36] Singh R, Switala J, Loewen PC, Ivancich A. Two [Fe(IV)=O Trp*] intermediates in $M$. tuberculosis catalase-peroxidase discriminated by multifrequency $(9-285 \mathrm{GHz})$ EPR spectroscopy: reactivity toward isoniazid. J Am Chem Soc 2007;29:15954-63.

[37] Suarez J, Ranguelova K, Schelvis JP, Magliozzo RS. Antibiotic resistance in Mycobacterium tuberculosis: peroxidase intermediate bypass causes poor isoniazid activation by the $\mathrm{S} 315 \mathrm{G}$ mutant of $M$. tuberculosis catalase-peroxidase (KatG). J Biol Chem 2009;284:16146-55.

[38] Brossier F, Veziris N, Truffot-Pernot C, Jarlier V, Sougakoff W. Performance of the Genotype MTBDR line probe assay for detection of resistance to rifampin and isoniazid in strains of Mycobacterium tuberculosis with low- and high-level resistance. J Clin Microbiol 2006;44:3659-64.

[39] Cardoso RF, Cooksey RC, Morlock GP, Barco P, Cecon L, Forestiero F, et al. Screening and characterization of mutations in isoniazid-resistant Mycobacterium tuberculosis isolates obtained in Brazil. Antimicrob Agents Chemother 2004;48:3373-81.

[40] Musser JM, Kapur V, Williams DL, Kreiswirth BN, van Soolingen D, van Embden JD. Characterization of the catalase-peroxidase gene $(\mathrm{kat} G)$ and $i n h A$ locus in isoniazid-resistant and -susceptible strains of Mycobacterium tuberculosis by automated DNA sequencing: restricted array of mutations associated with drug resistance. J Infect Dis 1996;1731:196202.

[41] Ando H, Kondo Y, Suetake T, Toyota E, Kato S, Mori T, et al. Identification of katG mutations associated with high-level isoniazid resistance in Mycobacterium tuberculosis. Antimicrob Agents Chemother 2010;54:1793-9.

[42] Vilchèze C, Jacobs WR Jr. Resistance to isoniazid and ethionamide in Mycobacterium tuberculosis: genes, mutations, and causalities. Microbiol Spectr 2014;2:MGM2-0014-2013.

[43] Sekiguchi J, Miyoshi-Akiyama T, Augustynowicz-Kopeć E, Zwolska Z, Kirikae F, Toyota E, et al. Detection of multidrug resistance in Mycobacterium tuberculosis. J Clin Microbiol 2007;45:179-92.

[44] Pym AS, Domenech P, Honore N, Song J, Deretic V, Cole ST. Regulation of catalaseperoxidase (KatG) expression, isoniazid sensitivity and virulence by furA of Mycobacterium tuberculosis. Mol Microbiol 2001;40:879-89. 
[45] Brossier F, Veziris N, Truffot-Pernot C, Jarlier V, Sougakoff W. Molecular investigation of resistance to the antituberculous drug ethionamide in multidrug-resistant clinical isolates of Mycobacterium tuberculosis. Antimicrob Agents Chemother 2011;55:355-60.

[46] Canetti G, Rist N, Grosset J. Measurement of sensitivity of the tuberculous bacillus to antibacillary drugs by the method of proportions. Methodology, resistance criteria, results and interpretation. Rev Tuberc Pneumol (Paris) 1963;27:217-72.

[47] Wengenack NL, Uhl JR, St Amand AL, Tomlinson AJ, Benson LM, Naylor S, et al. Recombinant Mycobacterium tuberculosis $\mathrm{KatG}(\mathrm{S} 315 \mathrm{~T})$ is a competent catalase-peroxidase with reduced activity toward isoniazid. J Infect Dis 1997;176:722-7.

[48] Marcinkeviciene JA, Magliozzo RS, Blanchard JS. Purification and characterization of the Mycobacterium smegmatis catalase-peroxidase involved in isoniazid activation. J Biol Chem 1995;270:22290-5.

[49] Saint-Joanis B, Souchon H, Wilming M, Johnsson K, Alzari PM, Cole ST. Use of sitedirected mutagenesis to probe the structure, function and isoniazid activation of the catalase/peroxidase, KatG, from Mycobacterium tuberculosis. Biochem J 1999;338:753-60.

[50] Singh R, Wiseman B, Deemagarn T, Jha V, Switala J, Loewen PC. Comparative study of catalase-peroxidases (KatGs). Arch Biochem Biophys 2008;471:207-14.

[51] Rawat R, Whitty A, Tonge PJ. The isoniazid-NAD adduct is a slow, tight-binding inhibitor of InhA, the Mycobacterium tuberculosis enoyl reductase: adduct affinity and drug resistance. Proc Natl Acad Sci USA 2003;100:13881-6.

[52] Singh R, Wiseman B, Deemagarn T, Donald LJ, Duckworth HW, Carpena X, et al. Catalase-peroxidases (KatG) exhibit NADH oxidase activity. J Biol Chem 2004;279:43098106.

[53] Pan L, Aller SG. Tools and procedures for visualization of proteins and other biomolecules. Curr. Protoc. Mol Biol 2015;110:19.12.1-19.12.47.

[54] Wengenack N L, Lane BD, Hill PJ, Uhl JR, Lukat-Rodgers GS, Hall L, et al. Purification and characterization of Mycobacterium tuberculosis KatG, KatG(S315T) and Mycobacterium bovis KatG(R463L). Protein Expr Purif 2004;36:232-43.

[55] Johnsson K, Froland WA, Schultz PG. Overexpression, purification, and characterization of the catalase-peroxidase KatG from Mycobacterium tuberculosis. J Biol Chem 1997;272:2834-40. 
[56] Wei CJ, Lei B, Musser JM, Tu SC. Isoniazid activation defects in recombinant Mycobacterium tuberculosis catalase-peroxidase (KatG) mutants evident in InhA inhibitor production. Antimicrob. Agents Chemother 2003;47:670-5.

[57] $\mathrm{Yu} \mathrm{S}$, Chouchane S, Magliozzo RS. Characterization of the W321F mutant of Mycobacterium tuberculosis catalase-peroxidase KatG. Protein Sci 2002;11:58-64.

[58] Baker RD, Cook CO, Goodwin DC. Properties of catalase-peroxidase lacking its C-terminal domain. Biochem Biophys Res Commun 2004;320:833-9.

[59] Smulevich G, Jakopitsch C, Droghetti E, Obinger C. Probing the structure and bifunctionality of catalase-peroxidase (KatG). J Inorg Biochem 2006;100:568-85.

[60] Vidossich P, Alfonso-Prieto M, Carpena X, Loewen PC, Fita I, Rovira C. Versatility of the electronic structure of compound $\mathrm{I}$ in catalase-peroxidases. $\mathrm{J}$ Am Chem Soc 2007;129:13436-46.

[61] Pym AS, Saint-Joanis B, Cole ST. Effect of katG mutations on the virulence of Mycobacterium tuberculosis and the implication for transmission in humans. Infect Immun 2002;70:4955-60. 
Table 1. Mutagenic primers employed in the site-directed mutagenesis of WT KatG using the QuickChange XL kit. The changed bases are in boldface.

\begin{tabular}{|c|c|}
\hline \multirow[t]{2}{*}{ A110V } & 5'-GGC GTG GCA CGC TGT CGG CAC CTA CCG CAT CC-3' \\
\hline & 3'-GG ATG CGG TAG GTG CCG ACA GCG TGC CAC GCC-5' \\
\hline \multirow[t]{2}{*}{ G118D } & 5'-CCG CAT CCA CGA CGA CCG CGG CGG C-3' \\
\hline & 5'-G CCG CCG CGG TCG TCG TGG ATG CGG-3' \\
\hline \multirow[t]{2}{*}{ G121D } & 5'-CGA CGG CCG CGG CGA CGC CGG GGG CGG C-3' \\
\hline & 3'-G CCG CCC CCG GCG TCG CCG CGG CCG TCG-3' \\
\hline \multirow[t]{2}{*}{ L141S } & 5'-CCC GAC AAC GCC AGC TCG GAC AAG GCG CG-3' \\
\hline & 5'-CG CGC CTT GTC CGA GCT GGC GTT GTC GGG-3' \\
\hline \multirow[t]{2}{*}{ A162E } & 5'-GCT CTC ATG GGA GGA CCT GAT TGT TTT CGC-3' \\
\hline & 5'-GCG AAA ACA ATC AGG TCC TCC CAT GAG AGC-3' \\
\hline \multirow[t]{2}{*}{ D189G } & 5'-GCT TCG GCC GGG TCG GCC AGT GGG AGC-3' \\
\hline & 5'-GCT CCC ACT GGC CGA CCC GGC CGA AGC-3' \\
\hline \multirow[t]{2}{*}{$\mathrm{R} 249 \mathrm{H}$} & 5'-CGG CGG TCG ACA TTC ACG AGA CGT TTC GG-3' \\
\hline & 5'-CC GAA ACG TCT CGT GAA TGT CGA CCG CCG-3' \\
\hline \multirow[t]{2}{*}{ H270R } & 5'-CGT CGG CGG TCG CAC TTT CGG TAA GAC CC-3' \\
\hline & 5'-GG GTC TTA CCG AAA GTG CGA CCG CCG ACG-3' \\
\hline \multirow[t]{2}{*}{ S315T } & 5'-GGA CGC GAT CAC CAC CGG CAT CGA GGT CG-3' \\
\hline & 5'-CG ACC TCG ATG CGG GTG GTG ATC GCG TCC-5' \\
\hline \multirow[t]{2}{*}{ L336P } & 5'-CCT CGA GAT CCC GTA CGG CTA CGA GTG GG-3' \\
\hline & 5'-CC CAC TCG TAG CCG TAC GGG ATC TCG AGG-3' \\
\hline \multirow[t]{2}{*}{ W341G } & 5'-CCT GTA CGG CTA CGA GGG GGA GCT GAC GAA GAG CC-3' \\
\hline & 5'-GGC TCT TCG TCA GCT CCC CCT CGT AGC CGT ACA GG-3' \\
\hline \multirow[t]{2}{*}{ Q461P } & 5'-CCA GCC TTA AGA GCC CGA TCC GGG CAT CGG G-3' \\
\hline & 3'-C CCG ATG CCC GGA TCG GGC TCT TAA GGC GGT-3' \\
\hline \multirow[t]{2}{*}{ R463L } & 5'-GCC AGC CTT AAG AGC CAG ATC CTG GCA TCG GGA TTG ACT G-3’ \\
\hline & 5'-C AGT CAA TCC CGA TGC CAG GAT CTG GCT CTT AAG GCT GGC-3' \\
\hline \multirow[t]{2}{*}{ G494D } & 5'-GGC GGC GCC AAC GAT GGT CGC ATC CGC CTG C-3' \\
\hline & 3'-G CAG GCG GAT GCG CCA ATC GTT GGC GCC GCC-5' \\
\hline R595 & 5'-GGC AGA TGG CTT CTG AAA CTA CCT CGG AAA GGG-3' \\
\hline
\end{tabular}


5'-CCC TTT CCG AGG GAT TTT CAG AAG CCA TCT GCC-3'

\begin{tabular}{ll}
\hline F658V & 5'-CAC TGA CCA ACG ACT TCG TCG TGA ACC TGC TCG-3' \\
& 5'-CGA GCA GGT TCA CGA CGT AGT CGT TGG TCA GTG-3' \\
\hline WT & 5'-CCC GTC GTG GGT CAC ${ }^{\text {a }}$ ATG AAA TAC CCC GTC G-5' \\
& 5'-CGA CGG GGT ATT TCA TGT GAC CCA CGA CGG G-3' \\
\hline
\end{tabular}

756

$757 \quad \mathrm{a}(\mathrm{nt} 75: \mathrm{T} \rightarrow \mathrm{C})$

758

759

760

761

762

763

764

765

766

767

768

769

770

771

772

773

774

775

776

777

778

779

780

781

782

783 


\begin{tabular}{|c|c|c|c|c|c|}
\hline \multirow[b]{2}{*}{$\mathrm{KatG}^{\mathrm{b}}$} & \multicolumn{4}{|c|}{ Enzymatic activity (U) ${ }^{a}$} & \multirow[b]{2}{*}{$\begin{array}{l}\text { Level of } \\
\text { INH } \\
\text { resistance }^{c}\end{array}$} \\
\hline & Catalase & Peroxidase & $\begin{array}{c}\text { Free radical } \\
\text { production }\end{array}$ & $\begin{array}{l}\text { Isonicotinoyl-NAD } \\
\text { formation }\end{array}$ & \\
\hline WT & $2023 \pm 58$ & $0.91 \pm 0.03$ & $2.01 \pm 0.15$ & $0.78 \pm 0.02$ & $\mathrm{~S}$ \\
\hline non-His $_{6}$ WT & $2225 \pm 101$ & $0.89 \pm 0.04$ & $2.60 \pm 0.04$ & $0.73 \pm 0.02$ & $\mathrm{~S}$ \\
\hline H270R & $\begin{array}{c}<2 \\
(<0.1 \%)\end{array}$ & $\begin{array}{c}<0.01 \\
(<0.1 \%)\end{array}$ & $\begin{array}{c}<0.01 \\
(<0.1 \%)\end{array}$ & $\begin{array}{c}<0.01 \\
(<0.1 \%)\end{array}$ & R (HL10) \\
\hline R595STOP & $\begin{array}{c}<2 \\
(<0.1 \%)\end{array}$ & $\begin{array}{c}0.19 \pm 0.01 \\
(21 \%)\end{array}$ & $\begin{array}{c}0.28 \pm 0.02 \\
(14 \%)\end{array}$ & $\begin{array}{c}0.09 \pm 0.02 \\
(12 \%)\end{array}$ & $\mathrm{R}(\mathrm{HL} 10)$ \\
\hline L336P & $\begin{array}{c}<2 \\
(<0.1 \%)\end{array}$ & $\begin{array}{l}0.23 \pm 0.02 \\
\quad(25 \%)\end{array}$ & $\begin{array}{l}0.38 \pm 0.04 \\
\quad(19 \%)\end{array}$ & $\begin{array}{l}0.12 \pm 0.01 \\
\quad(15 \%)\end{array}$ & $\mathrm{R}(\mathrm{HL} 10)$ \\
\hline W341G & $\begin{array}{c}<2 \\
(<0.1 \%)\end{array}$ & $\begin{array}{c}0.31 \pm 0.03 \\
(34 \%)\end{array}$ & $\begin{array}{c}0.26 \pm 0.02 \\
\quad(13 \%)\end{array}$ & $\begin{array}{l}0.32 \pm 0.02 \\
\quad(41 \%)\end{array}$ & $\mathrm{R}(\mathrm{HL} 10)$ \\
\hline G118D & $\begin{array}{c}<2 \\
(<0.1 \%)\end{array}$ & $\begin{array}{c}0.27 \pm 0.01 \\
\quad(30 \%)\end{array}$ & $\begin{array}{c}0.16 \pm 0.04 \\
(8 \%)\end{array}$ & $\begin{array}{c}0.23 \pm 0.03 \\
\quad(29 \%)\end{array}$ & $\mathrm{R}(\mathrm{HL} 10)$ \\
\hline G121D & $\begin{array}{l}283 \pm 4 \\
(14 \%)\end{array}$ & $\begin{array}{c}0.40 \pm 0.01 \\
(44 \%)\end{array}$ & $\begin{array}{l}0.14 \pm 0.02 \\
\quad(7 \%)\end{array}$ & $\begin{array}{l}0.16 \pm 0.03 \\
\quad(21 \%)\end{array}$ & R (HL1) \\
\hline L141S & $\begin{array}{l}40 \pm 4 \\
(2 \%)\end{array}$ & $\begin{array}{c}0.41 \pm 0.04 \\
(45 \%)\end{array}$ & $\begin{array}{l}0.28 \pm 0.10 \\
\quad(14 \%)\end{array}$ & $\begin{array}{c}0.24 \pm 0.02 \\
\quad(31 \%)\end{array}$ & $\mathrm{R}(\mathrm{HL} 10)$ \\
\hline A162E & $\begin{array}{c}1416 \pm 40 \\
(70 \%)\end{array}$ & $\begin{array}{c}1.07 \pm 0.02 \\
(118 \%)\end{array}$ & $\begin{array}{l}0.52 \pm 0.06 \\
\quad(26 \%)\end{array}$ & $\begin{array}{l}0.44 \pm 0.01 \\
\quad(56 \%)\end{array}$ & $\mathrm{R}(\mathrm{HL} 10)$ \\
\hline $\mathrm{S} 315 \mathrm{~T}$ & $\begin{array}{l}1112 \pm 40 \\
(55 \%)\end{array}$ & $\begin{array}{l}0.64 \pm 0.04 \\
\quad(70 \%)\end{array}$ & $\begin{array}{l}0.18 \pm 0.02 \\
\quad(9 \%)\end{array}$ & $\begin{array}{l}0.08 \pm 0.01 \\
\quad(10 \%)\end{array}$ & R (HL1) \\
\hline Non-His $_{6} \mathrm{~S} 315 \mathrm{~T}$ & $\begin{array}{c}951 \pm 121 \\
(47 \%)\end{array}$ & $\begin{array}{l}0.47 \pm 0.01 \\
\quad(52 \%)\end{array}$ & $\begin{array}{l}0.18 \pm 0.02 \\
\quad(9 \%)\end{array}$ & $\begin{array}{l}0.07 \pm 0.01 \\
\quad(9 \%)\end{array}$ & R (HL1) \\
\hline G494D & $\begin{array}{c}870 \pm 40 \\
(43 \%)\end{array}$ & $\begin{array}{l}0.65 \pm 0.02 \\
(72 \%)\end{array}$ & $\begin{array}{l}1.04 \pm 0.04 \\
(52 \%)\end{array}$ & $\begin{array}{l}0.55 \pm 0.03 \\
\quad(70 \%)\end{array}$ & R (HL1) \\
\hline Q461P & $\begin{array}{c}890 \pm 20 \\
(44 \%)\end{array}$ & $\begin{array}{l}0.53 \pm 0.01 \\
(58 \%)\end{array}$ & $\begin{array}{l}0.90 \pm 0.06 \\
\quad(45 \%)\end{array}$ & $\begin{array}{l}0.55 \pm 0.04 \\
\quad(71 \%)\end{array}$ & $\mathrm{R}(\mathrm{LL})$ \\
\hline & & & 26 & & \\
\hline
\end{tabular}




\begin{tabular}{|c|c|c|c|c|c|}
\hline D189G & $\begin{array}{c}1072 \pm 182 \\
(53 \%)\end{array}$ & $\begin{array}{c}0.54 \pm 0.01 \\
\quad(59 \%)\end{array}$ & $\begin{array}{c}0.98 \pm 0.08 \\
\quad(49 \%)\end{array}$ & $\begin{array}{c}0.47 \pm 0.01 \\
\quad(60 \%)\end{array}$ & $\mathrm{R}(\mathrm{LL})$ \\
\hline $\mathrm{R} 249 \mathrm{H}$ & $\begin{array}{c}1497 \pm 61 \\
(74 \%)\end{array}$ & $\begin{array}{c}0.70 \pm 0.02 \\
(77 \%)\end{array}$ & $\begin{array}{c}1.63 \pm 0.14 \\
(81 \%)\end{array}$ & $\begin{array}{c}0.54 \pm 0.02 \\
\quad(69 \%)\end{array}$ & $\mathrm{R}(\mathrm{LL})$ \\
\hline F658V & $\begin{array}{c}1679 \pm 40 \\
(83 \%)\end{array}$ & $\begin{array}{c}0.99 \pm 0.03 \\
(109 \%)\end{array}$ & $\begin{array}{c}1.77 \pm 0.14 \\
(88 \%)\end{array}$ & $\begin{array}{c}0.61 \pm 0.02 \\
\quad(78 \%)\end{array}$ & $\mathrm{R}(\mathrm{LL})$ \\
\hline A110V & $\begin{array}{c}1436 \pm 40 \\
(71 \%)\end{array}$ & $\begin{array}{c}1.80 \pm 0.02 \\
(198 \%)\end{array}$ & $\begin{array}{c}1.47 \pm 0.04 \\
(73 \%)\end{array}$ & $\begin{array}{c}0.31 \pm 0.02 \\
(40 \%)\end{array}$ & $\mathrm{R}(\mathrm{LL})$ \\
\hline R463L & $\begin{array}{c}1598 \pm 101 \\
(79 \%)\end{array}$ & $\begin{array}{c}0.81 \pm 0.03 \\
(89 \%)\end{array}$ & $\begin{array}{c}2.05 \pm 0.06 \\
(102 \%)\end{array}$ & $\begin{array}{c}0.67 \pm 0.01 \\
(86 \%)\end{array}$ & $S$ \\
\hline
\end{tabular}

$786{ }^{\mathrm{a}}(\%)=$ Normalized to the value obtained for WT KatG as $100 \%$.

$787{ }^{\mathrm{b}} \mathrm{WT}=$ wild-type

$788^{\mathrm{c}} \mathrm{S}=$ susceptible; $\mathrm{R}=$ resistant; $\mathrm{LL}=$ low-level resistant, defined as resistant to $>0.1 \mathrm{but}<1 \mathrm{mg} / \mathrm{lof}$ $789 \mathrm{INH} ; \mathrm{HL}=$ high-level resistant, defined as resistant to $\geq 1 \mathrm{mg} / \mathrm{l} ; \mathrm{HLl}=$ resistant to $\geq 1 \mathrm{mg} / 1 \mathrm{but}<10$ $790 \mathrm{mg} / \mathrm{l} ; \mathrm{HL} 10=$ resistant to $\geq 10 \mathrm{mg} / \mathrm{l}$.

791

792

793

794

795

796

797

798

799

800

801

802

803

804

805

806

807 

KatG

\begin{tabular}{|c|c|c|c|}
\hline Classes of mutants & KatG & Location of the mutation & $\begin{array}{l}\text { Level of INH } \\
\text { resistance }\end{array}$ \\
\hline $\begin{array}{l}\text { Mutants with no detectable } \\
\text { enzymatic activity }\end{array}$ & H270R & $\begin{array}{l}\text { Loss of the coordination link } \\
\text { between } \mathrm{H} 270 \text { and the iron of the } \\
\text { heme }\end{array}$ & $\mathrm{R}(\mathrm{HL} 10)$ \\
\hline \multirow{6}{*}{$\begin{array}{l}\text { Mutants with drastically } \\
\text { decreased catalase and free } \\
\text { radical production activities }\end{array}$} & R595STOP & Deletion of the C-terminal domain & R (HL10) \\
\hline & W341G & $\begin{array}{l}\text { In the proximal pocket, close to } \\
\text { the proximal triad }\end{array}$ & $\mathrm{R}(\mathrm{HL} 10)$ \\
\hline & L336P & $\begin{array}{l}\text { In the proximal pocket, close to } \\
\text { the proximal triad }\end{array}$ & $\mathrm{R}(\mathrm{HL} 10)$ \\
\hline & G118D & $\begin{array}{l}\text { In the long tunnel connecting the } \\
\text { entrance to the distal pocket }\end{array}$ & $\mathrm{R}(\mathrm{HL} 10)$ \\
\hline & G121D & $\begin{array}{l}\text { In the long tunnel connecting the } \\
\text { entrance to the distal pocket }\end{array}$ & R (HL1) \\
\hline & L141S & $\begin{array}{l}\text { Next to the distal pocket and the } \\
\text { key catalytic residue } \mathrm{H} 108\end{array}$ & $\mathrm{R}(\mathrm{HL} 10)$ \\
\hline \multirow{2}{*}{$\begin{array}{l}\text { Mutants with drastically } \\
\text { decreased free radical } \\
\text { production activity but } \\
\text { retaining significant } \\
\text { catalase/peroxidase activity }\end{array}$} & S315T & $\begin{array}{l}\text { In the short channel connecting the } \\
\text { heme pocket to the outside of the } \\
\text { protein }\end{array}$ & R (HL1) \\
\hline & A162E & $\begin{array}{l}\text { In the long tunnel connecting the } \\
\text { entrance to the distal pocket }\end{array}$ & $\mathrm{R}(\mathrm{HL} 10)$ \\
\hline \multirow{5}{*}{$\begin{array}{l}\text { Mutants showing moderately } \\
\text { decreased enzymatic } \\
\text { activities }\end{array}$} & G494D & Remote from the heme & R (HL1) \\
\hline & Q461P & Remote from the heme & $\mathrm{R}(\mathrm{LL})$ \\
\hline & D189G & Remote from the heme & $\mathrm{R}(\mathrm{LL})$ \\
\hline & $\mathrm{R} 249 \mathrm{H}$ & $\begin{array}{l}\text { At the edge of the heme pocket, } \\
\text { with a solvent-exposed side-chain }\end{array}$ & $\mathrm{R}(\mathrm{LL})$ \\
\hline & F658V & Remote from the heme & $\mathrm{R}(\mathrm{LL})$ \\
\hline $\begin{array}{l}\text { Mutants displaying a } \\
\text { moderate effect on catalase } \\
\text { and INH activation, with an } \\
\text { increased peroxidase activity }\end{array}$ & A110V & $\begin{array}{l}\text { At the level of the heme pocket, } \\
\text { not far from the catalytic residue } \\
\text { H108 and the M255-Y229-W107 } \\
\text { adduct }\end{array}$ & $\mathrm{R}(\mathrm{LL})$ \\
\hline $\begin{array}{l}\text { Mutants that do not modify } \\
\text { the free radical production } \\
\text { activity and do not confer } \\
\text { INH-R }\end{array}$ & $\mathrm{R} 463 \mathrm{~L}$ & Far from the heme & $\mathrm{S}$ \\
\hline
\end{tabular}


Figure 1. Three-dimensional representation (ribbon model) of KatG of $M$. tuberculosis (PDB entry 2CCA).

The heme prosthetic group and the catalytic His108 are shown in black. The mutated residues are represented using red sticks for His270, Trp341, Leu336, Leu141, Ser315, Ala162, Gln461, Asp189, Arg249, Phe658, Ala110 and Arg463, while red spheres are used to represent Gly118, Gly121 and Gly494. The segment of polypeptide chain deleted in the Arg595STOP mutant is shown in orange. The numerous tryptophan, tyrosine and methionine residues present in KatG are shown as thin blue lines. Water molecules (cyan and blue spheres) indicate the location of the two access channels to the heme: a long and wide channel (filled by water molecules represented in blue) that extends from the surface of the protein to the catalytic residue His108, and a narrower short channel connecting the distal heme pocket to the protein surface at the level of residue S315 (corresponding to the water molecules represented in cyan). The yellow INH molecules (NIZ) indicate four potential INH binding sites in KatG which have been positioned by superimposing the 3D structures of KatG of M. tuberculosis, S. elongatus and B. pseudomallei [24, 25, 28]. The binding site corresponding to NIZ-803, which is generally considered to be the main INH binding site in KatG, has been inferred from cristallographic structures of class I, II, III peroxidases in complex with INH or other small aromatic compounds of similar structure to INH [17, 21-23]. It is located in the narrowest part of the channel connecting the distal heme pocket to the protein surface at the level of S315, hence at the entrance to the $\varepsilon$-edge side of the heme [25]. Structural comparisons have revealed that the identity and configuration of the residues in the binding site corresponding to NIZ-803 are very similar among S. elongatus KatG, B. pseudomallei KatG, and M. tuberculosis KatG. NIZ-802 and NIZ-804 have been recently identified in KatG of S. elongatus, at the level of the entrance to the $\gamma$-edge side of the heme and in front of the heme propionate side chain, respectively [25], and NIZ-749 in KatG of B. pseudomallei at the entrance of a long channel connecting the distal pocket to the outside of the protein [24]. In contrast to the binding site corresponding to NIZ-803, the environment of NIZ-802 and NIZ-804 are structurally more diverse among the three KatG proteins of S. elongatus, B. pseudomallei, and M. tuberculosis. Image constructed using PyMOL [53]. 


\section{Figure 2. Close-ups showing structural details in three regions of KatG.}

845 The legend is the same as in Figure 1. 2A, view of the mutated residues in the proximal pocket 846 (His270, Leu336 and Trp341, in red). Trp321 (forming a transient tryptophan radical), Asp381 and 847 Met377 are depicted as blue sticks. Distances (in $\AA$ ) are indicated by black dotted lines. 2B, view of 848 the mutated residues in the distal pocket (Gly118, Gly121, Leu141, Ala162, Ser315, Asp189 and 849 Ala110, in red). Two Arg residues (Arg418 and Arg484 potentially interacting with residues 118 850 and 121), are shown as blue sticks. The Met255-Tyr229-Trp107 adduct is visible close to His108. 851 The two arrows indicate the opening of the two access channels. H-bonds are depicted as blue 852 dotted lines. 


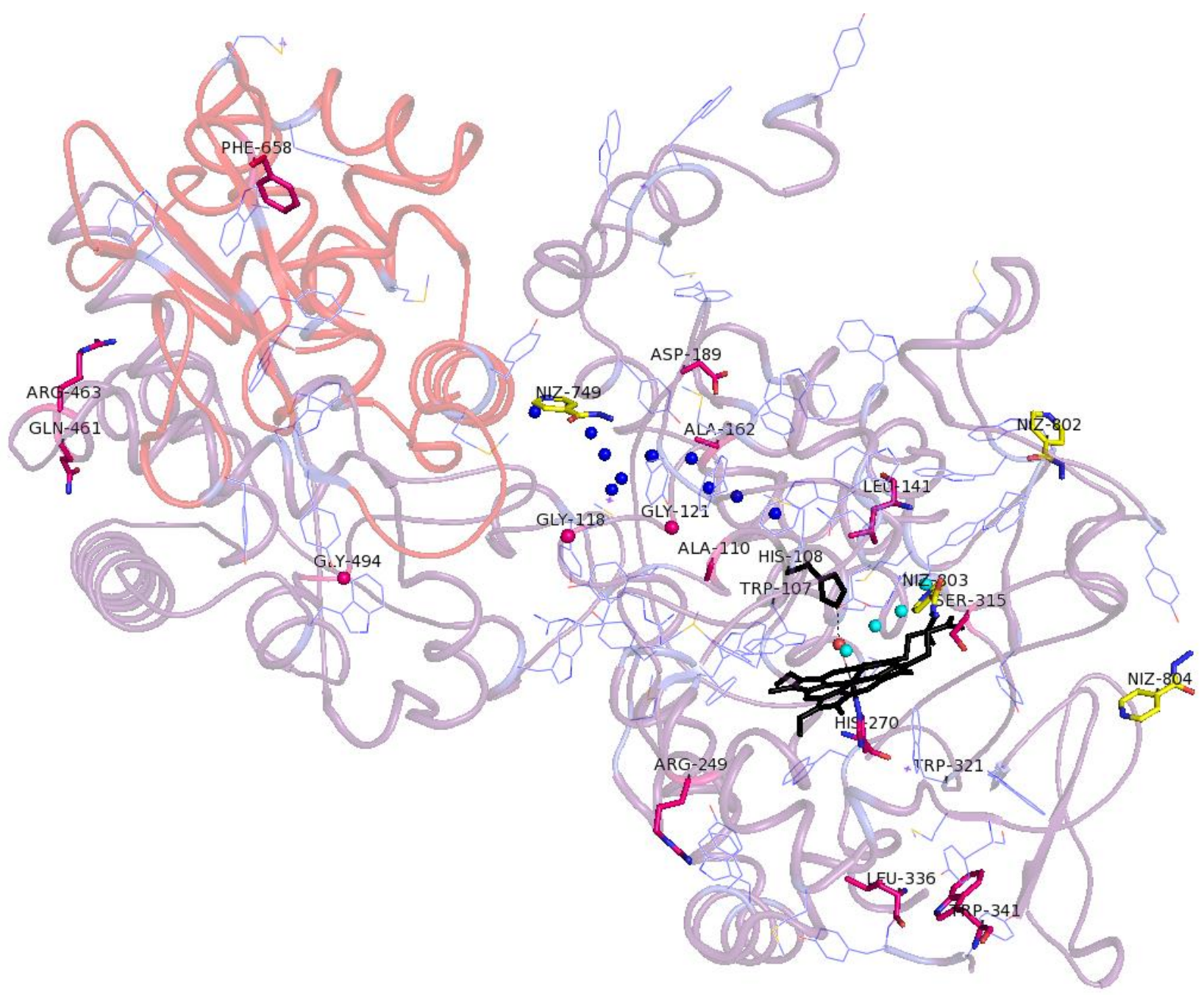

Figure 1 
A

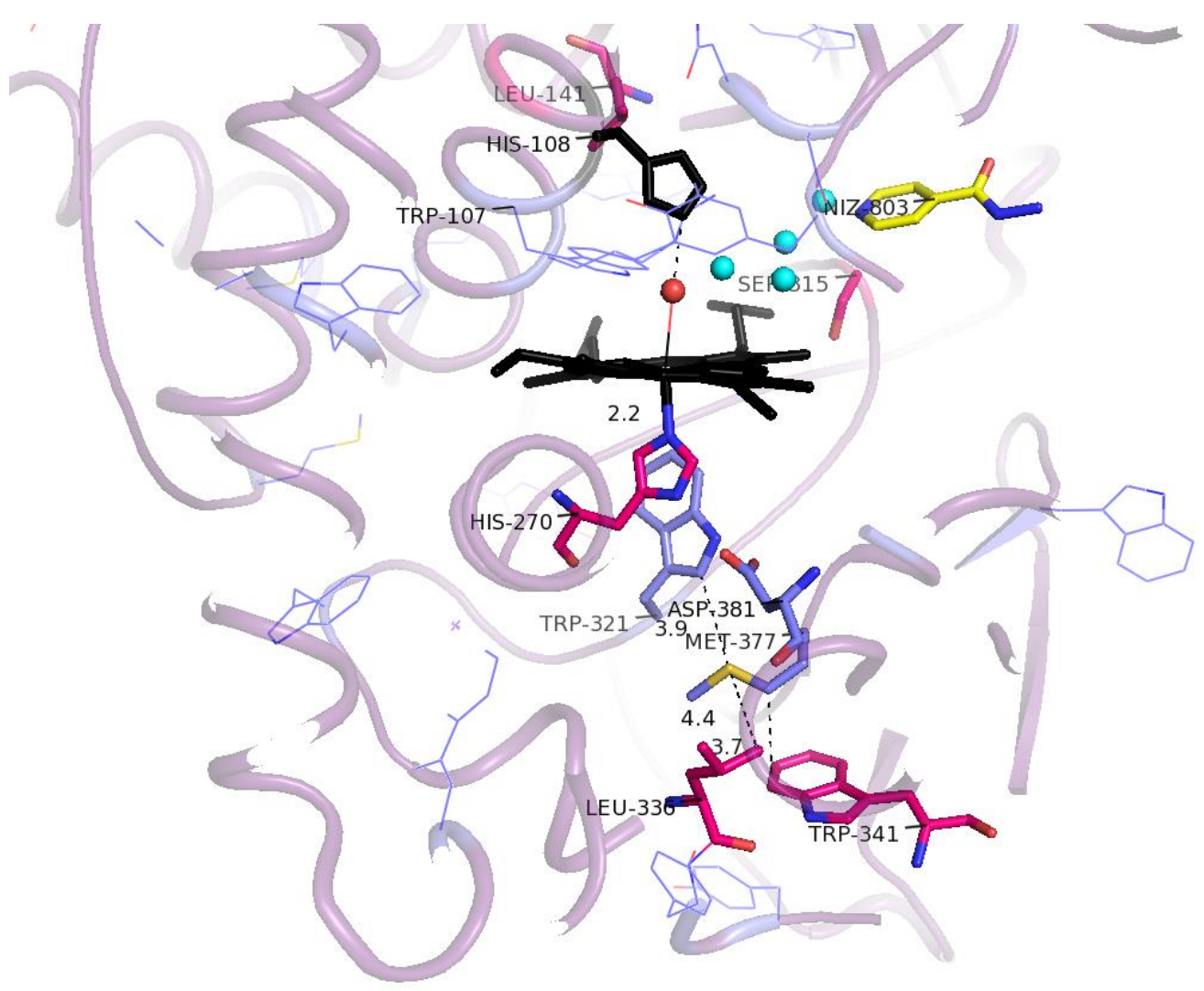

B

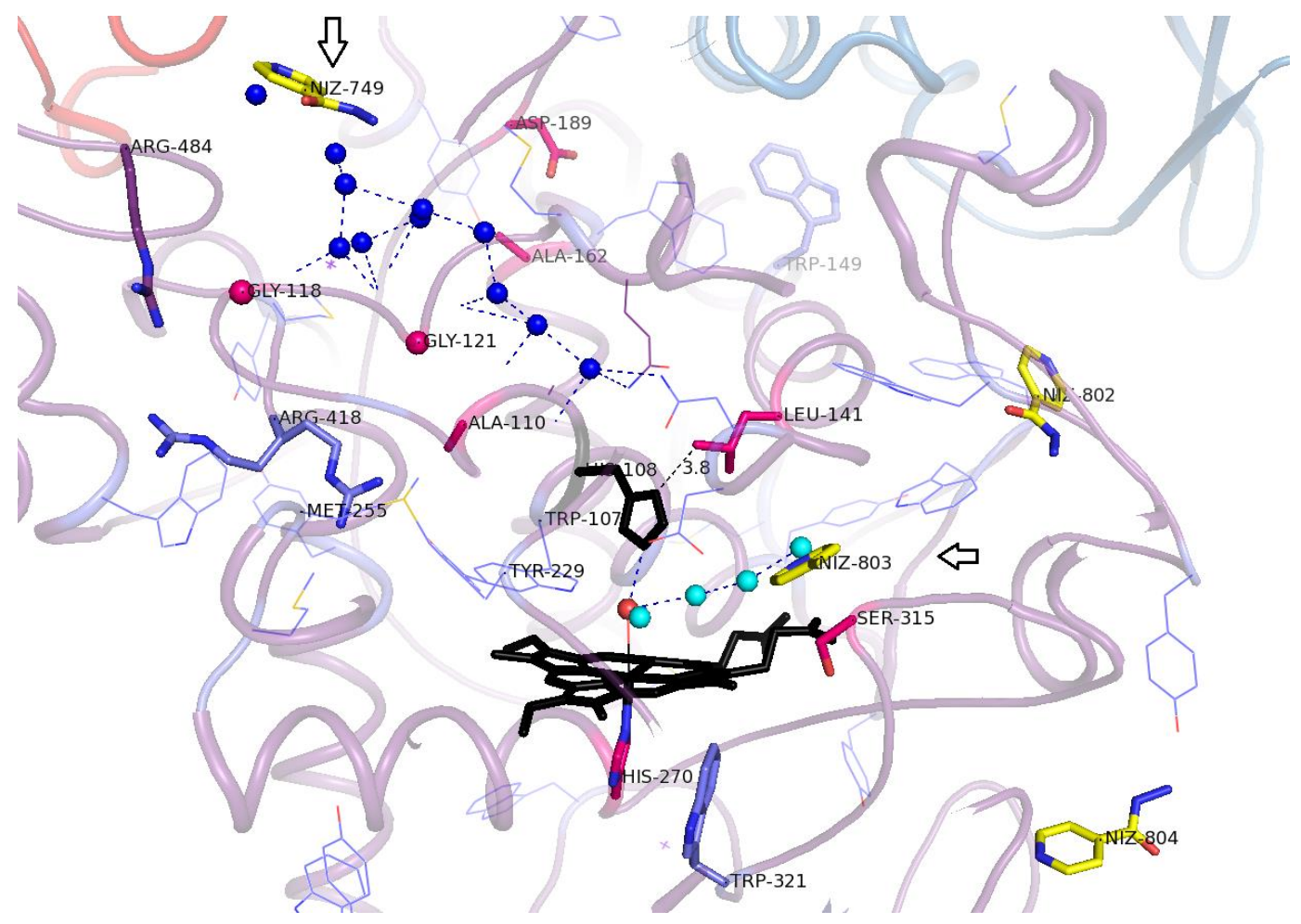

Figure 2 